\title{
FRENCH WORKERS AND THE TEMPERANCE MOVEMENT*
}

In 1852, when the medical discoverer of alcoholism, Magnus Huss, was being honoured by the Académie française, a spokesman for the Académie wrote that "France has many drunkards, but happily, no alcoholics."1 Sixty years later, on the eve of World War I, if one is to believe the reports of parliamentary commissions, economists, hygienists and social reformers, France had few drunks but a plethora of alcoholics, from the Breton peasant who fed calvados to his children to the worker of Paris and the Midi who had abandoned wine, that "natural and hygienic drink", for the evils of mass-produced industrial alcohol, especially absinthe. ${ }^{2}$ By 1914, alcoholism was considered one of the three grands fléaux, or great plagues, that had struck France in the late nineteenth century, and it was blamed for all the ills of society, from a rising rate of criminality, suicide and mental illness to depopulation, revolutionary worker movements and even feminism. Alcoholism was, therefore, not just an individual misfortune, but a national tragedy. It had become, in the words of Clemenceau, "the whole social problem"3 and as such required the mobilized forces of the country to conquer it.

If alcoholism was considered a national calamity, one sector of the population, namely the working class, was thought to be both particularly vulnerable and culpable. Misery, it was believed, was largely caused by alcoholism and temperance propaganda invariably drew on the lives of the most visibly miserable, the urban workers, for examples to illustrate the evils of excessive drink. Emile Zola's novel L'Assommoir dramatized the problem, and among workers themselves there was the widely known

* The author gratefully acknowledges the assistance of a Canada Council grant in the preparation of this article.

1. I. Tournan, Le Régime de l'alcool, sa réforme nécessaire (Paris, 1916), p. 101.

2 By the law of March 23, 1903, industrial alcohol was defined as any alcohol other than natural (wines, cider, rum, beer, etc.); most such alcohol was made from beets, molasses or grains and production was centered in the North.

3 G. Clemenceau, Le Grand Pan (Paris, 1896), p. 270. 
stereotype of the alcoholic worker, the "sublime". ${ }^{4}$ It was often stated, without statistical evidence, that four-fifths of alcohol consumption was by workers 5 and, in many minds, alcoholism merged with the whole "worker problem". Modern research has proven that alcoholism knows no economic or class boundaries and, as a result, those who warned against the evils of drink have been dismissed as middle-class moralizers who sought to deprive workers of the consolation of drink and who, because of their ineffective methods and narrow attitudes, had no impact on the working class. But if there is no evidence to suggest that alcoholism was limited to the working class, there are indications that it was a problem and one that was bound to grow with increasing prosperity. There were those within the working class who recognized the danger and sought to make their comrades aware of the results of excessive drink. They were aided to a certain extent by the major temperance associations, which, though often riddled with false medical and social ideas, to say nothing of decidedly eccentric and contentious personalities, were able to establish ties with working-class groups by appealing to them on their own terms. By 1914, the foundations had been laid in France for what would become, during the First World War, a type of anti-alcoholic Union sacrée, a joining together of all classes to fight the so-called enemy within, alcoholism.

The tendency of many to exaggerate the dangers of drink and to make alcoholism the scapegoat for the ills of modern society should not obscure the fact that alcoholism was a growing problem in France. From 1840 to 1914, according to official statistics, alcohol consumption rose from 18 litres per adult inhabitant to 30 litres, making the French the largest consumers of alcohol in the world. ${ }^{6}$ Modern statistical research has suggested that this rate of alcohol consumption would indicate that a significant proportion of the adult population, about seven percent, were dangerously heavy drinkers, consuming approximately one quarter of all alcohol production. ${ }^{7}$ A particularly worrisome aspect of the pre-1914 statistics was the growth in the consumption of absinthe, a strong drink

4 The term "the sublime" came from the very popular book by Denis Poulot, Le Sublime (Paris, 1870). The book was said to be a source for Zola's L'Assommoir, cf. Joseph Reinach, Contre l'alcoolisme (Paris, 1911), p. 20.

5 Louis Jacquet, L'Alcool, étude économique générale (Paris, 1912), p. 716.

6 Sully Ledermann, Alcool, alcoolisme, alcoolisation, I, pp. 64-65. In his two-volume work Alcool, alcoolisme, alcoolisation (Paris, 1956-64) Ledermann gives an excellent survey of modern statistical and scientific research on alcoholism in France. For a more detailed discussion of French drinking patterns in the latter part of the nineteenth century see Michael R. Marrus, "Social Drinking in the Belle Epoque", in: Journal of Social History, VII (1973-74), pp. 115-41.

7 Ledermann, Alcool, alcoolisme, alcoolisation, I, p. 127. 
with rapidly destructive characteristics. ${ }^{8}$ In all likelihood, the official production and consumption statistics for alcohol are lower than reality because of the peculiar French institution, the bouilleur de cru (inadequately translated as private distiller). Any farmer in France who grew grapes, apples, pears, plums or cherries had the right to make brandy from his crops without being taxed. In 1914 there were about one million bouilleurs de cru in France ${ }^{9}$ and the ambulatory still was a common feature of the landscape at harvest time. Although legal limits were set for this untaxed production, it was well known that fraud was the norm and, as one President of France remarked, "A bouilleur de cru who did not defraud the government would be a saint." 10 It is likely that any production and consumption figures for alcohol are an underestimation of at least fifteen percent, although some people argue fifty to one hundred percent. Not surprisingly, in the same period the number of débits de boisson (bars, cafés, cabarets) had risen from a national average of one for every 116 inhabitants in 1850 to one for every 83 in $1914 .^{11}$ This development was aided by the abrogation of the laws controlling the establishment of cabarets and cafés, so that after 1880 it was possible for anyone to open a débit simply by going to the police station and filling out the necessary forms.

This disturbing rise in the consumption of alcohol was commonly attributed to a growth in urban poverty, and both working-class and middle-class observers agreed that people drank because they lived in misery. This assumption was buttressed by a variety of studies which purported to prove, by means of long parallel columns of statistics on the rising rate of criminality, suicide and insanity, that alcoholism was a working-class disease that would eventually destroy society. Not only were these statistical studies often invalid - as one critic argued, you could display alcohol consumption figures and taxation figures in parallel columns and argue that increased taxation was driving Frenchmen to drink $^{12}$-, but the basic association of alcoholism with poverty is suspect. The more probable explanation of the rising rate of alcohol consumption in the late nineteenth century was France's industrial progress and its increasing prosperity. It was, for example, the new scientific and technical

${ }^{8}$ Consumption of absinthe had grown from 15,000 hectolitres (of pure alcohol) in 1875 to 239,000 hectolitres by 1913 . Journal Officiel, Débats parlementaires, Chambre des députés, annexe à la séance du 19 janvier 1915, No 535, pp. 2-3.

9 Ledermann, Alcool, alcoolisme, alcoolisation, I, p. 43.

${ }_{10}$ Reinach, Contre l'alcoolisme, op. cit., p. 55.

11 Tempérance, 1897, p. 192; Journal Officiel, Débats parlementaires, Chambre des députés, July 11, 1912, "Rapport supplémentaire de la commission d'hygiène publique", No 2179 , p. 8.

12 Emile Duclaux, L'Hygiène sociale (Paris, 1902), p. 206. 
knowledge that enabled Frenchmen to industrialize the production of alcohol from the sugar beet as well as from molasses, grains and potatoes. Although the sugar-beet industry had been introduced in the North of France by Napoleon I, it was not until the 1860's that it became widespread. Production of alcohol from sugar beets rose from 300,000 hectolitres in the 1850 's to more than 1.5 million hectolitres by 1914 , displacing the previously popular liquor made from wine. ${ }^{13}$ By 1914 there were over 1,500 apéritifs, mostly made from industrial alcohol, ${ }^{14}$ and the industry provided a very inexpensive drink. A shot or petit verre could be bought for ten centimes, much cheaper than alcohol made from wine and at times, particularly during the wine shortage caused by the phylloxera crisis of the 1880 's, than wine itself. Not only a cheap drink, but a more powerful one, as such alcoholic drinks contained 50 degrees or more of alcohol, while wine had only 10-15 degrees. It was also science, in the form of Louis Pasteur and his discoveries, that enabled the wine and beer industry to develop products that would not spoil quickly and that could be transported long distances by the new railway system.

The result was for France an important development in its economy. Only five of France's eighty-six departments produced no alcohol, ${ }^{15}$ and the industry in its various forms supported four to five million people, brought in twelve percent of the national budget and accounted for $31 / 2$ billion francs per year in business. ${ }^{16}$ Quite naturally, both the wine and sugar-beet groups were powerful and well-organized economic lobbies, who usually managed to exact important concessions from parliament. If nineteenth-century economic developments made more and cheaper alcohol available, they also created the means to buy the product. Far from being an indication of poverty, the increased alcohol consumption in France was, in the long run, a sign of growing material prosperity. As the extra-parliamentary commission on alcohol of 1902 noted in its report, "fifty years ago a bottle of wine or a petit verre was a luxury reserved for special occasions". ${ }^{17}$ The report went on to blame the current "democratization" of the use of alcohol on a general rise in the standard of living and a parallel increase in worker salaries. Similarly, Emile Vandervelde, the Belgian Socialist and temperance crusader, admitted that it was the more

13 Ministère des finances, Bulletin de statistique et de législation comparée, LXXVI (1914), p. 40.

14 Pour l'avenir du peuple, October 2, 1910.

15 Jacquet, L'Alcool, op. cit., p. 69.

16 Ibid., pp. 891-92.

17 Ministère des finances, Commission extraparlementaire des alcools, vins et spiritueux, Rapport général (Paris, 1906), p. 60. 
highly paid workers who seemed to be more susceptible to alcohol. ${ }^{18}$ Significantly, there was a very strong prejudice in the working class against water because it was the "drink of the poor". ${ }^{19}$ The very poor - whether peasants or workers - simply could not afford to drirk. Of course, the working class was not living in what would be considered acceptable conditions, and poor housing and bad food could certainly be an incentive to drink, but, on the whole, alcoholism seems, as one commentator remarked, to be a disease associated with modernity and the same developments that produced the worker produced increased consumption of alcohol. ${ }^{20}$ Thus when social observers in the nineteenth century became aware of the problems of industrialization and the emergence of the working class, it was natural that they associated the latter with the new disease, alcoholism.

If there is no real evidence to support the widespread assumption that alcoholism was predominantly a working-class affliction, neither is there any reason to consider that group immune. Not only did drink play an important role in the personal and occupational life of the workers, ${ }^{21}$ but the conviction that alcohol was beneficial to the health (a belief not entirely abandoned by the medical profession and assiduously encouraged by producers of alcohol) was widespread in the working class and difficult to eradicate. Even the most militant working-class spokesmen would admit that alcohol was a problem for the worker, although they pointed out, quite rightly, that it was not limited to that one class.

It was, however, worker alcoholism that received the most attention, and direct efforts to combat it were made by both middle-class temperance organizations and groups within the working class itself. The temperance associations were not so simplistic in their approach as some of their propaganda and most of their detractors suggested. On the whole, they were aware of the complexity of the problem and the necessity of fighting alcoholism by a variety of means. If they tended to view worker alcoholism as the most pressing, or, as one person wrote, the most interesting problem, ${ }^{22}$ they were also aware of the dangers of rural alcoholism and the need to educate the young. The first officially recognized temperance association was the Société française de tempérance. (It had been founded

18 VIle Congrès international contre l'abus des boissons alcooliques (Paris, 1900), I, p 280.

19 Fléau du siècle, September 15, 1908.

20 Edmond Bertrand, Essai sur l'intempérance (Paris, n.d.), p. 55.

21 For details, see Marrus, "Social Drinking", loc. cit., pp. 129-34.

22 Ministère des finances, Commission extraparlementaire des alcools, op. cit., p. 72. 
in 1872 as the Association française contre l'abus des boissons alcooliques, but within a year had adopted the less cumbersome title.) Its establishment was the logical outcome of a growing concern in medical and political circles about the dangers of alcoholism in France, a concern that was reinforced by the events of the Franco-Prussian War and the Commune, whose excesses were often attributed to drink. The founding members of the Société française de tempérance were either eminent men of science or those prominent in the political world, and their actions were based on knowledge of the most recent medical research plus a genuine desire for social reform. Its first president, Dr L. Lunier was inspector-general of state asylums and prisons, and had published papers on alcoholism and mental illness. Among the well-known political founders was Theophile Roussel, who fought for child-welfare legislation and who introduced the 1872 bill against public drunkenness. Within a year, the new temperance society could boast of such members as Louis Pasteur, Hippolyte Taine, Victor Duruy and the Duc de Broglie, as well as lesser figures from the political world and the Academies of Medicine and Science. They established a long tradition of learned and politically active men who were drawn to the temperance movement by their humanitarianism, and who believed that all social reform would be stillborn unless the problem of alcoholism was conquered first. The influential membership and a determination to keep the society neutral in political and religious matters soon brought rewards: in 1880 , the Société française de tempérance was classified as an organization "of public utility", a coveted designation that would be passed on to later associations.

Although the new group contained many talented men dedicated to the task of alerting public opinion to the dangers of alcohol, it lacked the breadth of vision and flair for publicity that could give it a widespread appeal. The organization focused its efforts on a narrow segment of medical and public opinion, and spent most of its funds promoting medical research or attempting to influence parliamentarians. Further medical research into the effects of alcohol was undoubtedly necessary, but it is unfortunate that the scientific experiments subsidized by the society proved ultimately useless, based as they were on the premise that industrial alcohol, or even essences, were the real cause of alcoholism, while consumption of wine, that natural product of French soil, would combat the disease. Their political pressure was marginally more successful. In 1894 they managed to convince the Minister of Education, Raymond Poincaré, to include obligatory temperance lessons in the primary-school curriculum, and in the National Assembly they were able to provoke some debate on the proliferation of cabarets and bouilleurs de cru. 
However, attempts to reach a wider and more popular audience were disappointing. The journal of the organization published articles whose length and scientific complexity ensured a low readership, and it was only in 1882 that one member hesitantly suggested that selected representatives of the press might be informed of the society's meetings. ${ }^{23}$ Contact with the working class was impeded by the very moralizing and patronizing tone of temperance propaganda. Workers, the society implied, owed their miserable state to their own moral weakness, laziness and lack of foresight in spending money on drink rather than saving for retirement. Typical of the organization's lack of understanding of worker conditions was its perception of the women of the working class. Although the temperance movement was anxious to recruit women, for it saw what success their participation had brought to foreign temperance groups, there was a tendency to blame the working-class wife for causing alcoholism by her perverse habit of going out to work. If she stayed home, keeping the house clean and decorated with flowers and cooking appetizing meals, so the argument went, then her husband would not spend his time in cabarets. The society did award medals to model temperate workers, but the conditions were strict. To qualify for a bronze medal, the lowest, a worker had to spend ten years of "honesty and temperance" in the same firm. ${ }^{24}$ It is difficult to imagine a more dubious incentive for anyone, worker or not, to forswear alcohol, and the result of all these efforts was, as temperance people later admitted, that they reached only the elite and the sober. ${ }^{25}$

By the mid 1890's, the Société française de tempérance was in a state of moral and financial collapse, its twenty-five-year effort mocked by the rapidly increasing alcohol-consumption statistics. Fortunately for the movement, the next decade brought an influx of new men who were more dynamic in their methods and broader in their perspectives. First to appear was the most conscientious and contentious personality of the whole temperance movement, Dr Paul-Maurice Legrain, the director of Villejuif and later Ville-Evrard, the only Paris asylums for the alcoholic insane. Legrain, who had published an influential book on the hereditary effects of alcoholism, was well aware of the physical ravages of the disease, but his real concern was the more practical problem of how to convince people not to drink. The earlier temperance movement had failed, he argued, because it had remained too academic and scientific, and had neglected to spread its propaganda among all levels of society. ${ }^{26}$ In 1895 Legrain started his

23 Tempérance, 1882, p. 51.

24 Ibid., 1879, p. 173.

25 Ibid., 1895, p. 3.

26 Alcool, January 20, 1896, p. 1. 
own temperance society, the Union française antialcoolique, dedicated to making temperance a popular movement, particularly in the working class. Legrain brought two much-needed talents to the temperance movement, a sound practicality and a gift for propaganda. He was an indefatigable speaker and usually accompanied his speeches with slides of the malformed and imbecilic offspring of alcoholics, apparently a popular type of presentation. By 1905, the Union française antialcoolique had 40,000 members in 150 sections, ${ }^{27}$ and Legrain had personally converted the assistants in his own asylum, members of the Federation of Healthworkers, to the cause of anti-alcoholism. Legrain's only fault, at least in the eyes of other temperance people, was that he was one of the few total abstainers in France, a man who stubbornly and vocally proclaimed that wine was as dangerous to the health as industrial alcohol. His militancy on this subject was upsetting to the majority of temperance leaders who were trying to disassociate temperance from the traditional image of "teetotalism".

While Legrain was building his new organization, others tried to revive the moribund Société française de tempérance. The most important of these new men was Emile Cheysson, a prominent writer on social reform and active in associations to protect the family and workers. Cheysson agreed with Legrain that the time for research had ended and that temperance associations must now begin to act. With the help of his associate, Fréderic Riémain, he called for a total reorganization of the Société française into a new federation, grouping all the temperance associations in France under one common programme and dedicated to a great crusade against alcoholism. In 1903, after several years of hard work and considerable diplomatic manoeuvring on the part of Cheysson and Riémain, the new movement, renamed the Ligue nationale contre l'alcoolisme, emerged. It united a number of temperance groups, including the Union française antialcoolique, various Catholic and Protestant organizations and some worker sections into a loose federation, again neutral in political and religious matters, with each section having the freedom to adopt whatever methods it considered best to combat alcoholism. The new league inherited the old society's designation of "public utility", and continued to fight for legislation against cabarets and bouilleurs de cru. More important than any organizational change was the new spirit of dynamism and zeal that infused the league. Propaganda was now to be widespread, particularly among youth and worker groups, and the old moralizing lectures were abandoned in favour of simple, effective slogans and posters that would

${ }^{27}$ Maurice Habert, Les Ligues antialcooliques en France et à l'étranger (Paris, 1904), p. 134. 
appeal to the reader's physical and material well-being. The programme that emerged from the 1903 unifying congress contained a much stronger commitment to social reform, and the Ligue nationale recognized that its efforts among the working classes would be useless unless it supported such reforms as better worker housing and improved factory conditions. The new approach was effective, and by 1914 the Ligue nationale had over 125,000 members. ${ }^{28}$ Thus, despite the fact that the French temperance movement had been established in 1872, it was not until nearly thirty-five years later that there was a temperance organization whose size and philosophy gave it any chance of making an impact on the working class.

The Ligue nationale was well aware of the problems of attempting temperance propaganda in a country where social traditions and economic interests promoted the consumption of alcohol. At the 1903 congress, one member suggested that temperance would be the work of the twentieth century, ${ }^{29}$ and perhaps he was excessively optimistic. Although many organizations in France recognized the dangers of alcoholism, they preferred to tackle them indirectly, by improving worker housing or diet, and they restricted any direct action to pious resolutions voted at annual meetings. Temperance groups were invariably short of money, while having to fight powerful and wealthy alcohol and wine interests. Membership in temperance associations was difficult to attract because anti-alcoholism was not as socially acceptable as the fight against tuberculosis, and, of course, full members had to make a personal commitment to abstain from alcohol (but not wine) for a certain period of time, unless it was prescribed by a doctor. It was also difficult to combat the traditional skepticism of the French, in this case about the chances of persuading anyone to stop drinking; the familiar refrain was "qui a bu, boira". The national penchant for ridicule seemed to have a paralyzing effect on temperance people, who constantly alluded to the heavy burden of raillery that had to be borne by any temperance speaker.

Temperance groups were further handicapped by a case of mistaken identity. They were often characterized as buveurs d'eau, an insulting epithet at any time in France, but particularly in this period, when water supplies were often typhoid-ridden. In reality, all major temperance organizations not only allowed wine, they firmly advocated it, often in quite eloquent terms, as long as it was taken in moderation, a phrase which usually meant one litre of wine per day for adults and nothing for children

${ }^{28}$ Etoile Bleue, July-August 1914, p. 140.

${ }^{29}$ Premier congrès national contre l'alcoolisme, Compte rendu général (Paris, 1904), p. 180. 
under ten. As a result of this policy, French temperance groups were made to feel decidedly uncomfortable at international temperance congresses, where most participants were total abstainers, but it was probably a realistic approach given French conditions. (France is perhaps the only country in the world where a wine-grower like Emile Cheysson could become the most energetic and devoted head of the major temperance union.)

It was particularly difficult for the largely middle-class temperance associations to reach a working-class audience. Anti-alcoholism was often associated in worker minds with employers who "encouraged" temperance by firing anyone found drunk on the job (a convenient device for getting rid of troublemakers) or who claimed that the company was not responsible for accidents on the job because the worker involved was an alcoholic. Idealistic middle-class youths who ventured into worker universities to preach temperance were likely to be met by well-deserved skepticism. It was obviously necessary to find workers themselves who would set a temperate example to their comrades. But this too was a problem, for alcoholism did not receive much attention in organized working-class circles. This neglect was not the result of a belief that alcohol posed no problem for the working class. On the contrary, no worker spokesman ever denied the existence of alcoholism, but there was a strong feeling that it was not a problem that needed to be solved by immediate direct action. The most popular argument was the Marxist one that if alcoholism was a problem for the working class, it was one created by an industrial capitalism that produced cheap alcohol and worker misery. Alcoholism was seen as a useful tool created by the industrial bourgeoisie to keep workers docile, ignorant and poverty-stricken. Because alcoholism was a product of industrial capitalism, it was argued, it would disappear with the worker revolution, and therefore the best way to fight alcohol was to build up the strength and militancy of worker organizations. This theory was particularly strong amongst trade unionists and in the Guesdist branch of the Socialist Party, where anti-alcoholism, along with anticlericalism, antimilitarism and antifreemasonry, was denounced as a deviation.

Essentially a justification for inaction, this theory was founded on an ignorance of the complexity of the alcoholic problem. The Belgian Socialist Emile Vandervelde, whose own party supported a temperance campaign, attacked French Socialists and syndicalists for their complacency, and he pointed out that alcoholism was not solely the product of industrial misery. Many middle-class people were alcoholics, he argued, and studies had shown that more highly paid workers tended to drink more. He also wondered how a revolution or a new society could be 
made with workers brutalized by drink. ${ }^{30}$ Vandervelde's words were not well received in French circles; he was criticized for speaking at middleclass temperance meetings, and his facts about more highly paid workers were seen as an encouragement to employers who did not want to raise wages. Even the moderate wing of the French Socialist Party was confused about the problem, and its rare efforts at a solution were devoted to establishing a state monopoly of industrial alcohol. Equally uninformed about medical facts, they believed that alcoholism was caused by the quality, rather than the quantity, of alcohol ingested, and state rectification of industrial alcohol satisfied not only their hygienic interests, but the Socialist goal of the nationalization of essential industries. Even the besteducated representatives of working-class life did not understand this difficult problem. In a chapter on workers and alcoholism in his book $L a$ Vie ouvrière, Fernand Pelloutier, the founder of the Bourses du Travail, argued that the disease was caused by impure alcohol and that the problem would only disappear with the amelioration of the workers' living conditions. ${ }^{31}$ Behind all this misinformation and neglect lay practical political considerations. The base of the Guesdist party was in the North, where many relied on the alcohol industry for employment, while in the Midi both the Socialists and the syndicalists hoped to expand into the winegrowing areas, where poor economic conditions had produced a militant agricultural movement and the growth of co-operatives.

As a result of this lack of interest, there was little organizational support for any direct action to combat alcoholism in the working class, and concerned individuals often had to fight their union or party to make a case for anti-alcoholic propaganda. It was only very slowly, after 1900 , that worker temperance groups began to emerge; their development is difficult to trace because they were often scattered and associated with one individual or with a small group at the local level of a union, political party or Bourse du Travail. There was, for example, Auguste Keufer, of the printing trade union, who had been doing anti-alcoholic work among the members of his union for thirty years, although the results were not always evident in the union's newspaper. ${ }^{32}$ Jules Hayaux, a Socialist schoolteacher in the provinces, organized worker groups wherever he went, and the peregrinations of his academic career can be traced by a trail of worker temperance leagues. At the state arsenal in Brest, a group of workers led by J.-B. Bannier started an association that would later become the backbone of a

${ }^{30}$ Emile Vandervelde, Essais socialistes: l'alcoolisme, la religion, l'art (Paris, 1906), pp. 32-70.

31 Fernand Pelloutier, La Vie ouvrière (Paris, 1975), pp. 314-22.

32 Revue Socialiste, LVI (1912), p. 217. 
united worker temperance movement. Some middle-class temperance groups had their own worker sections, such as those in the Vosges, which later affiliated with the Ligue nationale. There was a very successful antialcoholic group established among railway workers in 1903. It was disavowed by the militant railway workers' union because it was started by office employees and had the support of the management, but it spread throughout the whole railway system and had over six thousand members by $1914 .^{33}$ The movement appears to have been more successful in the provinces and it was not until 1909, after much effort, that a worker temperance group was established in Paris.

At the national level, the syndicalist and Socialist organizations were slow to recognize the problem. The Confédération Générale du Travail discussed the issue for the first time at its congress in 1898, at the request of the Union des syndicats de la Seine. The debate was heated but inconclusive, and a commission established to report on the question was equally divided: the majority, after a traditional denunciation of capitalism, called on the State to assure the purity of alcoholic products and urged members to fight for better working conditions. The minority rejected the appeal to the State and concluded that while there was no remedy except the complete emancipation of the worker, members could, if they wished, preach the message of temperance. ${ }^{34}$ The question of alcoholism was not to appear on the agenda of another CGT congress until 1912. In 1899 one Socialist group voted to wage a war against alcoholism and then closed their meeting with a punch d'adieu. ${ }^{35}$ Like their syndicalist colleagues, they did not discuss the issue again until 1912.

With so little encouragement from national worker organizations, those who were concerned about alcoholism continued their propaganda at the local level, or looked for some support to the Ligue nationale. These local initiatives could, however, be effective. For example, the worker temperance group at Alençon, led by Hayaux, managed to win the support of all but one of the unions in the city, and with the help of several other groups was able to bring the question before the national congress of the Bourses $d u$ Travail. ${ }^{36}$ However, there was no widespread co-ordination of effort, and it was not until 1909, after several failures, that a completely working-class organization, the Association des travailleurs antialcooliques, was established to unite the diverse worker temperance groups. The

33 Etoile Bleue, July-August 1914, p. 140.

34 Musée social, Circulaires, 1899, No 2, pp. 81-83.

35 Alcool, April 1900, p. 58.

36 Jules Hayaux, L'Education antialcoolique dans les milieux ouvriers (Paris, n.d.), p. 6. 
association, later known as the Fédération des ouvriers antialcooliques, was founded by a group of militant unionists, with the aim of spreading the anti-alcoholic message amongst organized labour. The original organizer was E. Quillent, of the Union des syndicats de la Seine, and he soon attracted other union members such as Gustave Cauvin of the construction workers, L. Buis of the gas union, Th. Gaubert of the healthworkers' union, and A. Daudé-Bancel, a developer of co-operatives. Members of the Brest arsenal anti-alcoholic group gave their strong support and it was their newspaper, Le Réveil, which eventually became the propaganda organ for the federation. Although some people who were not union members were allowed to join - Dr Legrain was the most prominent example -, the council had to be composed of unionized workers.

The declared aim of the Fédération des ouvriers antialcooliques was revolutionary: to undermine capitalism by dissolving one of the strongest chains that bound the worker, alcohol. Their propaganda, designed to appeal to a CGT heavily imbued with revolutionary syndicalism, was based on a sound appreciation of the interests of the organized worker. Gone was the moralizing tone of previous temperance propaganda. As Quillent said, he did not care what workers did with their money as long as they did not spend it on drink. ${ }^{37}$ Instead, workers were shown how alcoholism weakened the worker movement and delayed the eventual revolution. Alcoholic workers, it was argued, were unreliable in times of strikes, were unfaithful union members, and would always settle for lower wages and poor working conditions. A great deal of the federation's propaganda was aimed at countering the popular Guesdist argument that anti-alcoholism was a deviation from real revolutionary goals. Quillent and others used the arguments made familiar by Vandervelde to show that the revolution would never arrive if the workers spent all their time in the cabarets. The federation also tried to destroy the familiar prejudices in favour of alcohol, particularly the idea that alcohol was a source of physical strength. It sought members who did heavy manual labour and yet were abstainers, and Buis gave a number of popular lectures on how he had been able to maintain a physically demanding job for eight years while drinking only water or tea.

Quillent, Cauvin and the other supporters of the federation were careful to keep the tone of their propaganda revolutionary and to link it to current concerns of the unions. When the CGT launched its campaign for the eight-hour day, the federation gave it strong support, arguing that shorter working hours would reduce the time spent in the cabaret. One of the most

37 Pour l'avenir du peuple, November 28, 1909. 
popular of the CGT posters for the campaign showed a man who worked long hours going into a cabaret to drink absinthe, while the same worker, under the eight-hour day, would spend the time with his family. In 1913, when the three-year army-service bill became a major issue among worker organizations, the federation entitled its propaganda "Two Enemies: Militarism and Alcoholism", and argued that an extra year in the barracks would only be an extra year in which recruits would learn to drink. The worker temperance association also allied itself with the small but popular working-class group, the neo-Malthusians. Cauvin was also a prominent neo-Malthusian propagandist and he combined his two passions, or antipassions, with great facility, arguing that alcoholism encouraged the procreation of too many children, thereby hampering the development of the working class. This neo-Mathusian side of their propaganda was also helpful in attracting women to the temperance movement. Like its middle-class counterparts, the federation appealed to women, but not in traditional terms. Women were told that they were doubly exploited - at work with lower salaries and in the home by alcoholic husbands - and that the destruction of alcohol would lead to their own liberation.

Quillent and his associates were also adept at using incidents that had aroused the workers. For example, in 1911 a militant union organizer of the dockers at Le Havre named Durand, who was also a militant anti-alcoholic campaigner, was arrested on insubstantial evidence and condemned to death. The Left launched a campaign to save him, strongly supported by the anti-alcoholic federation, which pictured Durand as a heroic unionist and anti-alcoholic militant unjustly condemned by a company and government that feared both his union and temperance activities. Dr Legrain, who was a very popular speaker for the federation, was particularly skilled in tailoring his message to a militant worker group and, with his ever-present slides of deformed children, he gave over thirty speeches on such topics as "Alcohol and War" and "The Enemy of the People". At times, the revolutionary aura was almost comic. In 1914, Quillent published a pamphlet entitled "Sabotage and Direct Action", which interested the police until they read it and found it was only an anti-alcoholic brochure. ${ }^{38}$.

The Fédération des ouvriers antialcooliques was indefatigable in its efforts to popularize anti-alcoholism in union circles. Quillent, Buis and Daudé-Bancel concentrated on placing temperance articles in the union newspapers and by 1914 anti-alcoholic slogans and messages appeared, with varying regularity and enthusiasm, in most of the union papers.

38 Archives Nationales $F^{7}$ 13594, September 13, 1912. 
Support for their efforts came from the leading worker newspapers like the La Bataille Syndicaliste and L'Humanité. But they received their strongest support from La Guerre Sociale, where Gustave Hervé, that curious prewar Socialist, was completely converted to the cause and launched a great temperance crusade, complete with anti-alcoholic coupons, which workers were to buy instead of drinks. Gustave Cauvin and Dr Legrain concentrated their efforts on popular meetings, usually with some important figure like Léon Jouhaux, leader of the CGT, as guest speaker. The federation was well aware of the problems of attracting people to an anti-alcoholic lecture, and while not going so far as one temperance worker, who argued that temperance meetings had to be cleverly disguised (in Brittany he suggested they be advertised under the slogan "Brittany for the Bretons"), ${ }^{39}$ it did try to make them as entertaining as possible. After some temperance and syndicalist messages, and the singing of the Internationale antialcoolique, there would be popular entertainment, sometimes by the well-known chansonnier Montéhus. Cauvin was quick to realize the potential of that recent invention, the motion picture, and he was soon touring France with a portable projector and anti-alcoholic films. These meetings proved very popular, often attracting over a thousand people, and the federation soon received subsidies from some unions and requests for conferences from many more. To compete with the cabaret, the federation tried to include the whole family in its activities and organized family excursions, sports meetings and balls. It also attempted such concrete action as trying to persuade the co-operative stores to prohibit the sale of alcohol. This was difficult as co-operatives realized a very large profit on this popular item, and the most that the temperance group could achieve was to convince the leading Paris co-operative, La Bellevoise, to ban absinthe. ${ }^{40}$

Despite its solidly working-class aura, the Fédération des ouvriers antialcooliques had strong links with the middle-class Ligue nationale. For several years the leadership of the Ligue had agreed that the absence of a purely working-class temperance organization was a serious handicap in their campaign, and in 1906 Riémain had attempted to remedy this by meeting with Quillent and other union men. ${ }^{41}$ They arranged for Vandervelde to speak in Paris and started a worker anti-alcoholic group which soon foundered. Riemain persisted and in 1909, with what was termed "discreet aid" by the Ligue nationale, the Association des travailleurs anti-

\footnotetext{
39 Premier congrès national contre l'alcoolisme, op. cit., p. 646.

40 Bataille Syndicalistz, April 2, 1914.

41 Ibid., February 13, 1917.
} 
alcooliques, later the Fédération des ouvriers antialcooliques, was founded. ${ }^{42}$ The Ligue nationale continued to support the new organization, providing it with a yearly subsidy and propaganda material. Cauvin's tours of France were jointly sponsored by the Ligue nationale and the Bourses du Travail, and the activities of the worker federation were given wide publicity in the Ligue's newspaper. In return the federation supported the Ligue's campaign against absinthe and also joined a middle-class anti-alcoholic crusade launched during the election campaign of 1914. In fact, the Ligue's experiment had proven so successful that it established another worker temperance organization, La Pensée Ouvrière, with the ubiquitous Hayaux as editor of its newspaper, to appeal to non-unionized workers. The links between the federation and the middle-class temperance groups were not merely financial. All the leading members of the federation were Good Templars, an international temperance organization with Socialist ties, which had a very limited membership in France. Its most prominent French adherent was Dr Legrain, who had organized the French section of the Good Templars and who was one of the most active supporters of the worker temperance movement. It was perhaps Legrain's influence that accounted for the federation's curious insistence on total abstinence, although extreme measures may have been thought more suitable to a revolutionary-syndicalist temperament.

The federation's connection with the Ligue nationale was not widely known and did not seem to harm its efforts. (Nor did the discovery of a police spy in its midst.) Support for the cause was very strong among those unions, like the glassworkers, the foodworkers, miners and building trades, which considered alcoholism an occupational disease, and from the healthworkers' union, whose members were employed in the state asylums and hospitals, and had direct evidence of the effects of alcohol. The question was increasingly discussed at the federation level of different unions and in 1912 was on the agenda for both the Socialist and CGT congresses. Hayaux's newspaper, La Pensée Ouvrière, also grew, with help from the Bourses du Travail, from 2,000 issues in 1911 to 13,000 by $1914 . .^{43}$ Further support for the anti-alcoholic cause came from the publication in 1912 of Marchands de Folie, by Léon and Maurice Bonneff. The Bonneffs, who wrote for the La Guerre Sociale and other worker newspapers, were widely respected for their studies of working-class life. In Marchands de Folie they ignored statistical studies in favour of graphic sketches of the effects of alcohol, as seen in the working-class cabarets of Paris, the

42 Etoile Bleue, January 1910, p. 9.

43 Hayaux, L'Education antialcoolique, op. cit., pp. 14-15. 
tâcherons of the construction industry and the bars of the dockers at Le Havre. Although impressionistic in style, the book was based on questionnaires that the Bonneffs had submitted to union leaders, and it vividly illustrated their belief that alcoholism was gnawing away at the nation. ${ }^{44}$

But if anti-alcoholism was making some impact on the working class, success was slow and hard-won. Not only were popular prejudices deeply rooted, but even those people committed to fighting alcoholism were suspicious of working-class temperance movements. At the foodworkers' congress of 1912, when members were urged to join the Fédération des ouvriers antialcooliques, there was opposition from unionists who argued that the federation might contain "disparate and hostile elements" and that "viruses even worse than alcoholism might slip in". ${ }^{45}$ The union finally decided to undertake its own temperance propaganda within the membership. Nor was union leader Jouhaux's war-time boast that the CGT had always supported the battle against alcohol strictly true. ${ }^{46}$ At the 1912 congress at Le Havre, the motion to have alcoholism discussed did not receive enough votes. It was only because a member of the federation was on the cost-of-living commission and was able to get a recommendation for a boycott of alcohol included in the commission's report that the congress finally voted a motion on alcoholism. ${ }^{47}$ At the Socialist Party congress of the same year, the issue provoked a long, bitter and ultimately inconclusive debate. While some urged the party to support temperance legislation, Guesde and his followers rejected any immediate action and continued to maintain that only the long-awaited Socialist revolution could solve the problem. ${ }^{48}$ When the journal Le Mouvement Social sent a questionnaire to unions on the problem of alcoholism, the results were not encouraging. Many unions did not bother to return the form, and those that did saw alcoholism as widespread and the means of combatting it weak and undeveloped. The Bonneffs' claim that union efforts had eradicated the "sublime", or alcoholic worker, was undoubtedly good propaganda, but not accurate reporting. ${ }^{49}$

The future, however, was encouraging. Members of the working class were increasingly aware of the problem of alcohol and, more important,

44 Léon and Maurice Bonneff, Marchands de folie (Paris, 1912), p. 3.

45 Fédération nationale des travailleurs de l'alimentation, Compte rendu et travaux et résolutions du VIIe congrès national (Courbevoie, 1912), p. 101.

46 Archives Nationales $\mathrm{F}^{\tau}$ 13594, February 26, 1916.

47 Hayaux, L'Education antialcoolique, p. 13.

48 Parti Socialiste, 9e Congrès National, Compte rendu sténographique (Paris, 1912), pp. 272-95.

49 Léon and Maurice Bonneff, La Classe ouvrière (Paris, 1911), p. 343. 
organizations had been set up which, however small, could continue the propaganda. By 1914, such advanced worker groups as the Socialist and syndicalist youth organizations had adopted the crusade against alcoholism as part of their programmes, and individual members had pledged a personal commitment to temperance. Nor had the anti-alcoholic movement as a whole succumbed to class hostility. Both the Ligue nationale and the worker temperance organizations, if still struggling, were more successful than they had been in the past thirty years. Contrary to accepted views, the Ligue was not a completely bourgeois organization, with no awareness of the worker situation, nor were the workers themselves unresponsive to the dangers of alcohol. The way was open for the further co-operation of the two forces, after the outbreak of war, in a renewed temperance campaign against "the enemy within". 